\title{
Effect of Cigarette Smoking on the Structure of Hepatocytes: TEM Study
}

\author{
Efecto del Tabaquismo Sobre la Estructura de los Hepatocitos: Estudio MET
}

Khairat A. Battah*; Darwish H. Badran** \& Ziad A. Shraideh***

BATTAH, K. A.; BADRAN, D. H. \& SHRAIDEH, Z. A. Effect of cigarette smoking on the structure of hepatocytes: TEM Study. Int. J. Morphol., 34(4):1239-1244, 2016.

SUMMARY: The liver is one of the major organs that is indirectly affected by cigarette smoke. The aim of this project is to define the histologic and ultrastructural changes in normal liver cells after exposing animals to cigarette smoke. Thirty albino rats were exposed to cigarette smoke for 90 days, followed by morphologic examination of their livers under light microscope and electron microscope. The liver cells of cigarette smoke exposed rats showed mild swelling with increased eosinophilia. Ultrastructural examination of these cells demonstrated cytoplasm with highly proliferated and crowded mitochondria. There were many electron dense mitochondria. These mitochondria were pleomorphic in shape compared to mitochondrias of control rats. Also, loss of mitochondrial cristae and widening of the intermembranous space was noticed. It is concluded that smoking exerts cellular damage and oxidative stress on normal liver cells resulting in ultrastructural changes.

KEY WORDS: Liver; Smoking; Mitochondria; Ultrastructure.

\section{INTRODUCTION}

Cigarette smoking exposes the body to more than 4000 toxins (Richter et al., 2008). These toxins have many deleterious effects on different body organs starting from the oral cavity (Mirbod \& Ahing, 2000), the first area of contact with cigarette toxins, to the lung (Shraideh et al., 2013), cardiovascular system (Lehmann et al., 2014) and other internal organs like liver which has no direct contact with the smoke. Within the oral cavity of human body, cigarette smoking can produce oral leukoplakia which might be associated with malignant transformation (Mirbod \& Ahing). Exposure of rats to cigarette smoke caused drastic histological changes in the tracheal epithelium including epithelial cells proliferation, disruption of its cilia, and presence of inclusion bodies. It also showed marked thickening in the alveolar wall, collapsed alveoli and blood extravasations (Shraideh et al.).

Many studies have been conducted to evaluate the effect of cigarette smoke on liver diseases but none had shown its effect on normal liver cell ultrastructure (Hezode et al., 2003; Azzalini et al., 2010; Zein et al., 2011; Dam et al., 2013). Smoking was associated with an increased risk of liver cirrhosis independent of alcohol intake (Dam et al.). Several epidemiological studies have suggested a relationship between cigarette smoking and severity of liver disease in patients with chronic liver disease (Hezode et al.; Azzalini et al.; Zein et al.). Cigarette smoking aggravated the histological activity of hepatitis C (Hezode et al.), it exacerbated liver injury in a rat model of obesity related fatty liver, particularly it increased hepatocellular apoptosis and oxidative stress (Azzalini et al.). Cigarette smoking significantly increased the extent of hepatocellular ballooning and lobular inflammation, thereby increasing the NAFLD activity score in obese rats (Azzalini et al.). Histological picture of neonate rats liver that were exposed to cigarette smoke during fetal life showed parenchymal inflammation and cellular degeneration in liver parenchyma (Diniz et al., 2013). In this study, histopathologic changes in the liver cells of rats that were exposed to cigarette smoke were evaluated by light and electron microscopy.

\footnotetext{
* Department of Pathology, Microbiology and Forensic Medicine, The University of Jordan, Amman, Jordan.

** Department of anatomy and Histopathology, Faculty of Medicine, The University of Jordan, Amman, Jordan.

**** Department of Biology, Faculty of Science, The University of Jordan, Amman, Jordan.
} 


\section{MATERIAL AND METHOD}

Thirty male albino rats (rattus norvegicus), with an average weight of 100-150 g were divided into two equal groups. The first group (experimental) was exposed to cigarette smoke (1 cigarette/rat/day/for 90 days). Exposure to smoke was conducted using an electronically controlled smoking machine described by Shraideh et al. (2011). The second group (control) was placed in chambers and was allowed to breathe fresh air all the time. On the 91st day, rats were sacrificed by ether anesthesia. The liver was gently dissected and washed well with normal saline $(0.9 \% \mathrm{NaCl})$, cut into small pieces and fixed in $3 \%$ glutaraldehyde for at least $24 \mathrm{~h}$. To ensure adequate fixation, the formalin fixative was used at volume 10-20 times more than the volume of tissue pieces. Then the specimens were post-fixed in $1 \%$ osmium tetroxide for $1 \mathrm{~h}$. Each specimen was then dehydrated through a graded series of alcohols, infiltrated in spur epoxy resin and embedded. For light microscopic examination, sections (5-6 $\mu \mathrm{m}$ thick) were obtained by a microtome (Spencer 50), mounted on glass slides and stained with hematoxylin and eosin. For ultrastructure examination, the resin embedded tissue was cut at $60-90 \mathrm{~nm}$ thickness using an ultramicrotome (Leica, EM UC7) with a diamond knife. Sections were placed on grids, stained with uranyl acetate and lead citrate, and examined at different magnifications and photographed using Morgagni FEI 268 transmission electron microscope.

\section{RESULTS}

The present study evaluated the ultrastructural effects of cigarette smoking on rat liver histology. Ultrastructural examination demonstrated increase in the number of mitochondria, and the liver cell cytoplasm was crowded with mitochondria (Fig.1). There was thinning and disorganization of mitochondrial cristae with loss of matrix density (Figs. 2 and 3) and intramitochondrial amorphous deposits in liver cells of smoke exposed rats was noticed (Fig. 4). It was noticed also that there was noticeable proliferation of the endoplasmic reticulum (Fig. 5).

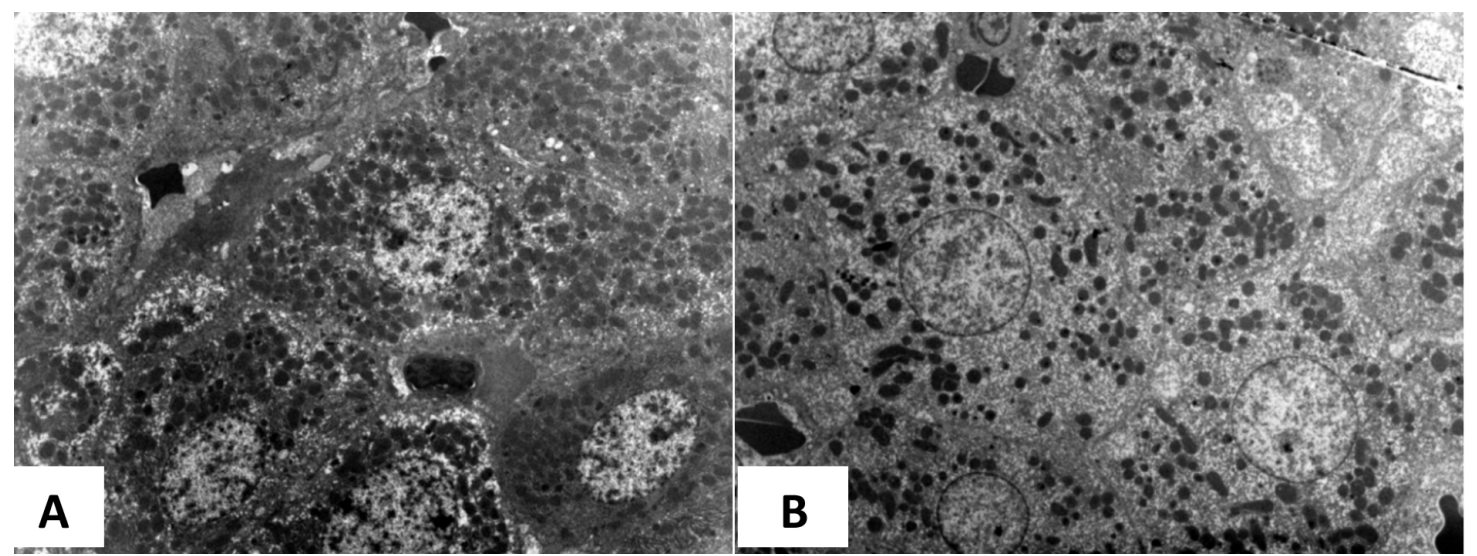

Fig. 1. Liver cell of rat exposed to cigarette smoke showing marked increase in number of mitochondria (A), compared with liver cell of control rats (B). (A,B X1800).
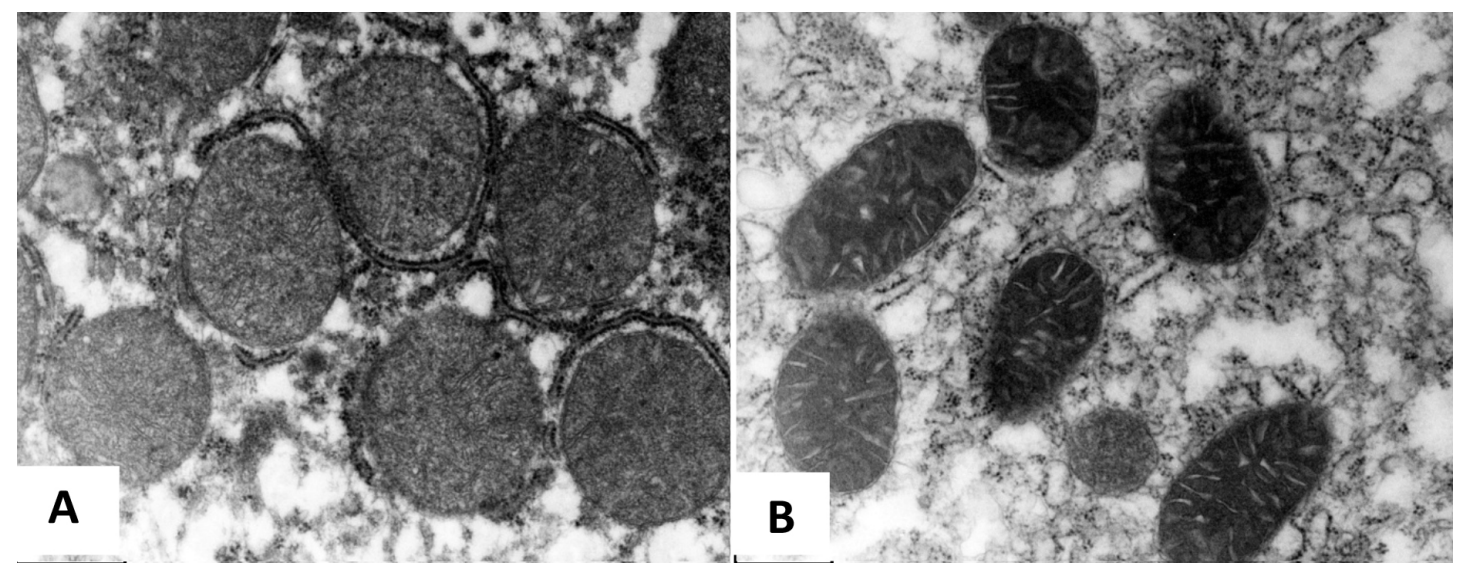

Fig. 2. Liver cell of rat exposed to cigarette smoke showing thinning and disorganization of mitochondrial cristea with decrease of matrix density (A), compared with liver cell from control rats (B). (A,B x22000). 


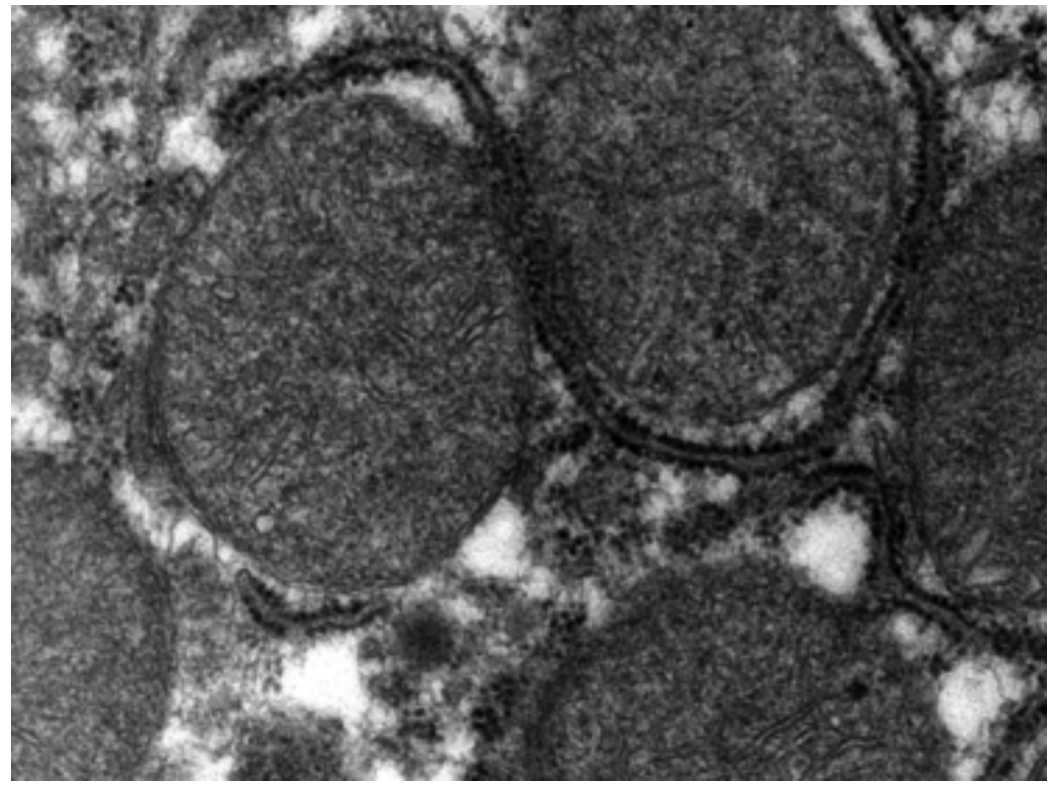

Fig. 3. Liver cell of rat exposed to cigarette smoke showing thinning and disorganization of mitochondrial cristea with decrease of matrix density. (x44000).

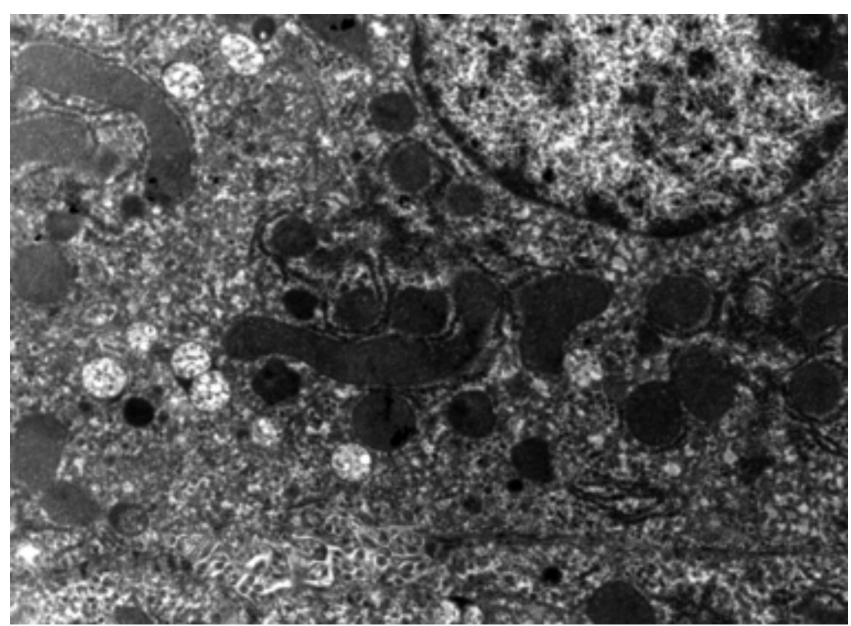

Fig. 4. Liver cell of rat exposed to cigarette smoke showing intramitochondrial amorphous deposits. (x7100).

\section{DISCUSSION}

The liver is a vital organ that has many tasks. Among other things, the liver is responsible for detoxifying drugs, alcohol and other toxins (Mescher, 2010; Rosai, 2011). Cigarette smoking induces three major adverse effects on the liver including immunological, oncogenic and other toxics effects (El-Zayadi, 2006). Smoking yields chemical substances with cytotoxic potentials. These chemicals created by smoking, induce oxidative stress associated with lipid peroxidation which leads to activation of stellate cells and development of fibrosis. In addition, smoking increases

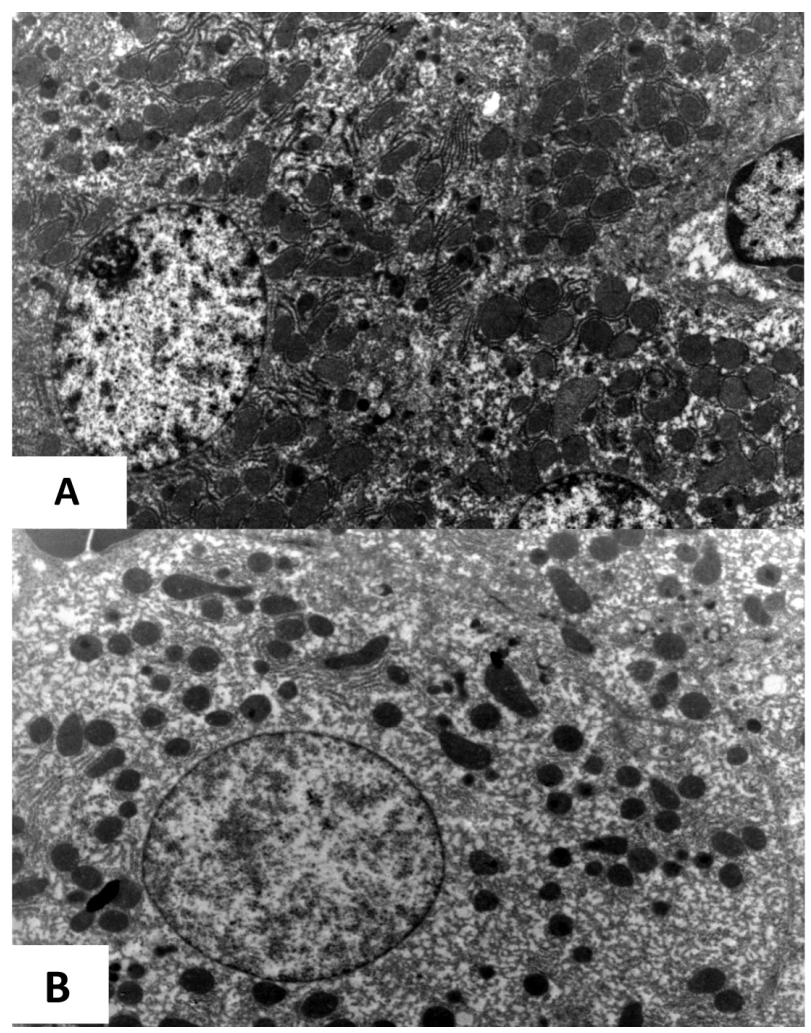

Fig. 5. Liver cell of rat exposed to cigarette smoke showing expansion of endoplasmic reticulum size (A), compared with endoplasmic reticulum of control rat liver cell (B). (A, B x3500).

the production of pro-inflammatory cytokines (IL-1, IL-6 and TNF- $\alpha$ ) involved in liver cell injury (El-Zayadi). Cigarette smoking increases the risk of developing 
hepatocellular carcinoma (HCC) among chronic liver disease (CLD) patients independently of liver status (El-Zayadi). Association of smoking with $\mathrm{HCC}$ has been reported, irrespective of Hepatitis B Virus (HBV) status (Wang et al., 2003; El-Zayadi). The liver lobes are made up of microscopic units called lobules which are roughly hexagonal in shape. The lobules are composed of rows of liver cells (hepatocytes) which radiate out from a central point (central vein) (Mescher; Rosai). This lobular architecture was preserved in rats exposed to cigarette smoke. The hepatic cells are in close contact with blood-filled sinusoids and also lie adjacent to canaliculi into which bile is secreted. Situated around the perimeter of the lobule are branches of the hepatic artery, hepatic portal vein and bile duct. These clusters, together at the "corners" of the lobule form what is called the portal triad (Mescher; Rosai). Although one study showed that chemicals created by cigarettes smoking induced oxidative stress associated with lipid peroxidation that leads to activation of stellate cells and development of fibrosis (ElZayadi), no histological evidence of fibrosis in the portal tract or perisinasoidal area was reported. Structurally, at the mid-point of the lobule is the central vein. Blood flows out of the sinusoids into the central vein and is transported out of the liver. The hepatocyte is round in shape containing a nucleus and an abundance of cellular organelles associated with metabolic and secretory functions. These organelles include endoplasmic reticulum (smooth and rough) and Golgi apparatus for secretory functions. Also there are high numbers of mitochondria to provide energy to support the many metabolic functions of the liver (Mescher).

The endoplasmic reticulum (ER) is a specialized organelle that has crucial roles in cell homeostasis and survival, which include protein folding, lipid biosynthesis, and calcium and redox homeostasis (Rutkowski \& Kaufman, 2004; Mescher). The lumen of the ER is the major site for proper protein folding and contains molecular chaperones and folding enzymes (Rutkowski \& Kaufman). In the liver, enzymes in the smooth ER metabolize and detoxify hydrophobic chemicals, such as drugs and carcinogens, and direct them for secretion from the body. (Schönthal, 2012). The accumulation of unfolded proteins in the endoplasmic reticulum (ER) represents a cellular stress induced by multiple stimuli and pathological conditions. These include hypoxia, oxidative injury, high-fat diet, hypoglycaemia, protein inclusion bodies and viral infection (Schönthal). A well-documented ultrastructural response to ER stress is displayed by the pronounced dilation of the ER lumen. For example, yeast cells expand their ER volume at least 5-fold under unfolded protein response-inducing conditions, and similar effects have also been confirmed in mammalian cells (Zuber et al., 2004). In our study it was noticed that there is noticeable expansion of the endoplasmic reticulum suggesting that cigarette smoking exerts cellular stress on liver cell. Increasing ER size through membrane synthesis is an integral part of the cellular program to overcome ER stress (Schuck et al., 2009).

Mitochondria are vital organelles that are involved in two fundamental functions: energy production through ATP synthesis (Mescher) and a central regulator of the decision between cellular survival and demise (Mescher). The structure of the mitochondria involves outer membrane, inner boundary membrane; inter membrane space, crystal membrane, and intercrystal space and matrix (Mescher). The mitochondria have a complex dynamic structure. Mitochondrial function is acknowledged to depend on the organelle's structure, where the organelle's structure, in turn, is controlled by cell function. From these reported experimental observations, it was deduced that changes in mitochondrial structure play an important role to the normal function of cells (McCarron et al., 2013).

The cytoplasm of nearly all eukaryotic cells contains mitochondria. They are especially abundant in cells and parts of cells that are associated with active processes (Caprette, 2005). For example, in flagellated protozoa or in mammalian sperm, mitochondria are concentrated around the base of the flagellum or flagella. In cardiac muscle, mitochondria surround the contractile elements (Caprette).

The double-membrane mitochondrion can be described as a large wrinkled bag packed inside of a smaller, unwrinkled bag. The two membranes create distinct compartments within the organelle, and are themselves very different in structure and in function. The membranes create two compartments. The intermembrane space, as implied, is the region between the inner and outer membranes. It has an important role in the primary function of mitochondria, which is oxidative phosphorylation (Caprette). The matrix contains the enzymes that are responsible for the citric acid cycle reactions. The matrix also contains dissolved oxygen, water, carbon dioxide, recyclable intermediates that serve as energy shuttles. Because of the folds of the cristae, no part of the matrix is far from the inner membrane (Caprette). These cristae are thinned in rats exposed to cigarette smoke. It is well know that smoking is associated with oxidative stress and experimental studies showed that mitochondria from cells treated with glucose oxidase appeared swollen with decreased electron density within the matrix and the cristae were noticeably thinner and often miss oriented and/ or decreased in number with intramitochondrial amorphous deposits that are likely represent matrix precipitates and degenerating cristae (Cole et al., 2010). These changes are similar to what is seen in mitochondria of liver cells of rats exposed to cigarette smoking. The authors of this project 
suggest that the thinning of cristae of the mitochondria of liver cells in rats exposed to cigarette smoke could be related to oxidative stress.

The changes that were seen in the mitochondria of the rats that were exposed to cigarette smoke are also seen in other diseases. One study showed that mitochondrial fragmentation and cristae alterations characteristic to cellular models of Huntington's disease and participated in their increased susceptibility to apoptosis (Costa et al., 2010). Alzheimer's disease mitochondrial morphology is altered in such a way that cristae are disrupted, and inclusions within mitochondria and varying types of inner membrane arrangements including concentric and parallel stacks of cristae membranes were observed (Zick et al., 2009).
Inclusions and altered cristae morphology were also found in the skeletal muscle of patients with amyotrophic lateral sclerosis (Boncompagni et al., 2012).

In conclusion, smoking exerts cellular and oxidative stress on normal liver cells resulting in ultrastructural changes.

\section{ACKNOWLEDGEMENTS}

This work was supported by a grant from the Deanship of Academic Research/ The University of Jordan (Grant number 2428/2014).

BATTAH, K. A.; BADRAN, D. H. \& SHRAIDEH, Z. A. Efecto del tabaquismo sobre la estructura de los hepatocitos: Estudio MET. Int. J. Morphol., 34(4):1239-1244, 2016.

RESUMEN: El hígado es uno de los principales órganos indirectamente afectado por el humo del cigarrillo. El objetivo de este trabajo fue definir los cambios histológicos y ultraestructurales de las células normales del hígado después de exponer a los animales al humo del cigarrillo. Treinta ratas albinas fueron expuestas al humo de cigarrillo durante 90 días, seguido de un examen morfológico de los hígados bajo microscopio de luz y microscopio electrónico. Las células hepáticas de las ratas expuestas al humo de cigarrillo mostraron una leve inflamación con un aumento de la eosinofilia. En el examen ultraestructural de estas células se observó el citoplasma mitocondrial altamente proliferado y saturado. Se observó gran cantidad de mitocondrias electrón-densas y éstas presentaban forma pleomórfica en comparación con las mitocondrias del grupo control. Además, se observó pérdida de las crestas mitocondriales y ensanchamiento del espacio intermembranoso. Se concluye que el tabaquismo ejerce daño celular y estrés oxidativo en las células hepáticas normales, lo que resulta en la aparición de cambios ultraestructurales.

\section{PALABRAS CLAVE: Hígado; Tabaquismo; Mitocondria; Ultraestructura.}

\section{REFERENCES}

Azzalini, L.; Ferrer, E.; Ramalho, L. N.; Moreno, M.; Domínguez, M.; Colmenero, J.; Peinado, V. I.; Barberà, J. A.; Arroyo, V.; Ginès, P.; Caballería, J. \& Bataller, R. Cigarette smoking exacerbates nonalcoholic fatty liver disease in obese rats. Hepatology, 51(5):1567-76, 2010.

Boncompagni, S.; Moussa, C. E.; Levy, E.; Pezone, M. J.; Lopez, J. R.; Protasi, F. \& Shtifman, A. Mitochondrial dysfunction in skeletal muscle of amyloid precursor protein-overexpressing mice. J. Biol. Chem., 287(24):20534-44, 2012.

Caprette, D. R. Evolutionary Origin of Mitochondria. En: Caprette, D. R. Experimental Biosciences. Sitio Web. Houston, Rice University, 2005. Available from: http://www.ruf.rice.edu/ bioslabs/studies/mitochondria/mitorigin.html

Cole, N. B.; Daniels, M. P.; Levine, R. L. \& Kim, G. Oxidative stress causes reversible changes in mitochondrial permeability and structure. Exp. Gerontol., 45(7-8):596-602, 2010.

Costa, V.; Giacomello, M.; Hudec, R.; Lopreiato, R.; Ermak, G.;
Lim, D.; Malorni, W.; Davies, K. J.; Carafoli, E. \& Scorrano, L. Mitochondrial fission and cristae disruption increase the response of cell models of Huntington's disease to apoptotic stimuli. E. M. B. O. Mol. Med., 2(12):490-503, 2010.

Dam, M. K.; Flensborg-Madsen, T.; Eliasen, M.; Becker, U. \& Tolstrup, J. S. Smoking and risk of liver cirrhosis: a populationbased cohort study. Scand. J. Gastroenterol., 48(5):585-91, 2013.

Diniz, M. F.; Dourado, V. A.; Silva, M. E.; Pedrosa, M. L.; Bezerra, F. S. \& Lima, W. G. Cigarette smoke causes changes in liver and spleen of mice newborn exposed during pregnancy. $J$. Cytol. Histol., 4:1000168, 2013.

El-Zayadi, A. R. Heavy smoking and liver. World J. Gastroenterol., 12(38):6098-101, 2006.

Hezode, C.; Lonjon, I.; Roudot-Thoraval, F.; Mavier, J. P.; Pawlotsky, J. M.; Zafrani, E. S. \& Dhumeaux, D. Impact of smoking on histological liver lesions in chronic hepatitis C. Gut, 52(1):126-9, 2003. 
Lehmann, N.; Möhlenkamp, S.; Mahabadi, A. A.; Schmermund, A.; Roggenbuck, U.; Seibel, R.; Grönemeyer, D.; Budde, T.; Dragano, N.; Stang, A.; Mann, K.; Moebus, S.; Erbel, R. \& Jöckel, K. H. Effect of smoking and other traditional risk factors on the onset of coronary artery calcification: results of the Heinz Nixdorf recall study. Atherosclerosis, 232(2):339-45, 2014.

McCarron, J. G.; Wilson, C.; Sandison, M. E.; Olson, M. L.; Girkin, J. M.; Saunter, C. \& Chalmers, S. From structure to function: mitochondrial morphology, motion and shaping in vascular smooth muscle. J. Vasc. Res., 50(5):357-71, 2013.

Mescher, A. L. Junqueira's Basic Histology. Text \& Atlas. $12^{\text {th }}$ ed. New York, McGraw-Hill, 2010.

Mirbod, S. M. \& Ahing, S. I. Tobacco-associated lesions of the oral cavity: Part I. Nonmalignant lesions. J. Can. Dent. Assoc., 66(5):252-6, 2000.

Richter, P.; Pechacek, T.; Swahn, M. \& Wagman, V. Reducing levels of toxic chemicals in cigarette smoke: a new Healthy People 2010 objective. Public Health Rep., 123(1):30-8, 2008.

Rosai, J. Rosai and Ackerman's Surgical Pathology. New York, Mosby, 2011.

Rutkowski, D. T. \& Kaufman, R. J. A trip to the ER: coping with stress. Trends Cell Biol., 14(1):20-8, 2004.

Schönthal, A. H. Endoplasmic reticulum stress: its role in disease and novel prospects for therapy. Scientifica (Cairo), 2012:857516, 2012.

Schuck, S.; Prinz, W. A.; Thorn, K. S.; Voss, C. \& Walter, P. Membrane expansion alleviates endoplasmic reticulum stress independently of the unfolded protein response. J. Cell Biol., 187(4):525-36, 2009.

Shraideh, Z. A. \& Najjar, H. N. Histological changes in tissues of trachea and lung alveoli of albino rats exposed to the smoke of two types of narghile tobacco products. Jordan J. Biol. Sci., 4(4):219-24, 2011.

Shraideh, Z. A.; Al-Awaida, W. \& Badran, D. Effects of cigarette smoking on histology of trachea and lungs of albino rat. Res. Opin. Anim. Vet. Sci., 3(10):356-62, 2013.

Wang, L. Y.; You, S. L.; Lu, S. N.; Ho, H. C.; Wu, M. H.; Sun, C. A.; Yang, H. I. \& Chien-Jen, C. Risk of hepatocellular carcinoma and habits of alcohol drinking, betel quid chewing and cigarette smoking: a cohort of $2416 \mathrm{HBsAg-seropositive} \mathrm{and}$ $9421 \mathrm{HBsAg}$-seronegative male residents in Taiwan. Cancer Causes Control, 14(3):241-50, 2003.

Zein, C. O.; Unalp, A.; Colvin, R.; Liu, Y. C.; McCullough, A. J. \& Nonalcoholic Steatohepatitis Clinical Research Network. Smoking and severity of hepatic fibrosis in nonalcoholic fatty liver disease. J. Hepatol., 54(4):753-9, 2011.
Zick, M.; Rabl, R. \& Reichert, A. S. Cristae formation-linking ultrastructure and function of mitochondria. Biochim. Biophys. Acta, 1793(1):5-19, 2009.

Zuber, C.; Fan, J. Y.; Guhl, B. \& Roth, J. Misfolded proinsulin accumulates in expanded pre-Golgi intermediates and endoplasmic reticulum subdomains in pancreatic beta cells of Akita mice. F. A. S. E.B. J., 18(7):917-9, 2004.

Correspondence to:

Darwish H. Badran

Department of Anatomy and Histology

School of Medicine

University of Jordan

Amman, 11942

JORDAN

Email: dhabdran@ju.edu.jo

Received: 11-06-2016

Accepted: 05-08-2016 